\title{
Proteção da Infância / Childhood Protection
}

https://doi.org/10.21814/uminho.ed.36.53

Maria João Leote de Carvalho

CICS.NOVA - Centro Interdisciplinar de Ciências Sociais da Faculdade de Ciências Sociais e Humanas da Universidade NOVA de Lisboa, Portugal

\section{Natália Fernandes}

Universidade do Minho, Instituto de Educação, CIEC e ProChild CoLAB, Portugal 



\section{Proteção da Infância ${ }^{13}$}

A ideia de proteção da infância é uma aquisição civilizacional relativamente recente, que começou a ganhar forma à luz das mudanças sociais, económicas e demográficas nas sociedades nascidas da industrialização no século XIX, marcadas pela emergência de uma ideologia de progresso, riqueza e bem-estar. Assenta num paradigma de conflito nas relações entre a Família e o Estado, construído com base num julgamento moral sobre o exercício da parentalidade nas classes populares, fortemente enraizado na distinção entre a redenção (da família) e a libertação (da criança), que nasce a edificação da proteção à infância. Era a segurança da própria sociedade, essencialmente dos grupos sociais dominantes, que acabava por ser posta em causa pela extensão dos problemas sociais.

A polarização em torno de duas posições diferenciadas nas respostas a implementar é imediata e permanece até aos dias de hoje. De um lado, quem defende a identificação e responsabilização dos pais que colocavam a crianças em situação de risco social; do outro lado, quem remete a solução do problema social para a reorganização das próprias instituições e do Estado (Digneffe, 1995).

A proteção à infância deve ter sempre no centro das preocupações o bem-estar da criança. Se no início, no século XIX, a preocupação estava restrita a um juízo moral sobre as classes populares e ao que se passava no seu seio,

13 A participação de Carvalho neste texto decorre de projeto de investigação apoiado pela FCT - Fundação para a Ciência e Tecnologia através de Bolsa individual de Pós-Doutoramento (SFRH/ BPD/116119/2016) com financiamento comparticipado pelo Fundo Social Europeu, no âmbito do POCH - Programa Operacional do Capital Humano, e por fundos nacionais do MCTES - Ministério da Ciência, Tecnologia e Ensino Superior. A investigadora Natália Fernandes é financiada por Fundos Nacionais através da FCT - Fundação para a Ciência e a Tecnologia no âmbito dos projetos do CIEC (Centro de Investigação em Estudos da Criança da Universidade do Minho) com as referências UIDB/00317/2020 e UIDP/00317/2020.

Carvalho acknowledges that her participation in this work was supported by the FCT - Fundação para a Ciência e Tecnologia through an individual Postdoctoral research grant (SFRH/BPD/116119/2016), under Operational Human Capital Program (POCH) funds, co-financed by the European Social Fund (ESF) and the Ministry of Science, Technology and Higher Education (MCTES). The researcher Natalia Fernandes is financially supported by Portuguese national funds through the FCT (Foundation for Science and Technology) within the framework of the CIEC (Research Center for Child Studies of the University of Minho) projects under the references UIDB/00317/2020 and UIDP/00317/2020. 
desde então, outras preocupações emergiram. Através da valorização da infância enquanto categoria social, iniciada na segunda metade do século XX nas sociedades ocidentais, a situação começou a alterar-se e de uma conceção estritamente centrada na dependência da criança perante o adulto, passou-se a outra que tem na sua centralidade a criança como sujeito de direitos e a condição específica da infância.

O foco da atenção veio a ultrapassar a esfera intrafamiliar para passar também a olhar para uma ampla variedade de ambientes e contextos de socialização da criança (creches, jardins de infância, escolas, associações, etc.) e a própria comunidade. Para este processo contribuíram os quadros sociais emergentes e as novas linhas de investigação sociológica que tenderam a centrar-se na análise de diferentes problemas sociais. Novas sensibilidades para casos outrora ocultos, ou de diferente visibilidade, começaram a ser postas para discussão.

Mais do que o eventual aumento dos riscos sociais, aquilo a que se poderá estar a assistir nos dias de hoje será antes um potencial aumento da sua representação no quotidiano em função da crescente visibilidade que certos atos adquirem, em parte fruto de uma mediatização permanente.

Atualmente, a representação da infância centra-se na necessidade da sua proteção e do desenvolvimento de políticas que efetivem os Direitos da Criança, proclamados em 1989, através da Convenção sobre os Direitos da Criança. A visão sobre a criança implícita na Convenção sobre os Direitos da Criança anula a anterior conceção da criança como objeto, "propriedade" dos seus pais / família, e é, também, clara na defesa da criança enquanto pessoa de pleno direito na sociedade, membro de uma família e comunidade, com direitos e responsabilidades adequados à sua idade, maturidade e desenvolvimento. Não se trata de um sujeito indefeso necessitado de mera caridade ou assistência. Trata-se de um cidadão, com direitos reconhecidos, e para que tal seja possível, é também prevista a responsabilidade de o Estado de garantir à família o apoio adequado e necessário para que seja assegurada a proteção e o desenvolvimento da criança.

Mas a realidade manifesta a ambivalência dos indivíduos e grupos sociais quando colocados perante estas questões e as imagens e as tensões resultantes entre proteção e participação, dependência e autonomia, mantêm-se e veem-se reproduzidas nos mais variados campos sociais. 
Da reflexividade que marca as sociedades ocidentais contemporâneas tem resultado a (re)descoberta dos riscos sociais que atravessam a infância, constatando-se, de modo claro, como a vida de muitas crianças, em diferentes pontos do mundo, se vê afetada por constrangimentos de natureza diversa. Vive-se um período de transição civilizacional marcado por acentuados progressos tecnológicos e económicos cujas repercussões, positivas e negativas, se fazem sentir a todos os níveis da ação humana (Beck, 2016).

As preocupações crescentes na atualidade, por exemplo, sobre a obesidade infantil, a saúde mental, os problemas de comportamento ou os usos da internet e das tecnologias digitais pelas crianças, nascem todas de uma mesma vontade de proteção à infância. Uma crescente complexidade a que corresponde a exigência de maior eficiência e eficácia das políticas públicas para a infância, onde o propósito deverá ser a organização de um sistema de proteção à infância, que não garanta apenas a sua proteção de danos graves (físicos, psicológicos ou sexuais), mas sobretudo garanta que vivem e crescem sob os cuidados adequados e eficazes que potenciem os seus direitos.

A proteção à infância assenta num delicado equilíbrio entre as relações dos cidadãos criança e pais e o Estado, em contextos em que se deseja que $o$ acesso à igualdade de direitos seja real e não apenas meramente formal. É este princípio que justifica e legitima a intervenção do Estado na regulação das esferas privada e pública. Todavia, ultrapassar discursos e práticas conflituantes e passar da "law-in-books" à "law-in-action" (Santos, 1986, p. 180) permanece como o maior desafio no tempo presente nas sociedades ocidentais e não apenas na área da infância, exigindo ir além do espaço marginal que a proteção à infância continua a ter na agenda pública, política e académica.

\section{Childhood Protection}

The idea of protecting childhood is a relatively recent development of civilisation which began to take shape because of social, economic and demographic changes in societies. These changes were the result of industrialization in the 19th century, underpinned by the emergence of an ideology of progress, wealth and well-being.

It is based on a paradigm of conflict in the relations between the family and the State, built on the basis of a moral judgment on the exercise of parent- 
ing in the working class. This is strongly rooted in the distinction between the rehabilitation (of the family) and liberation (of the child) in which child protection first appears. It was the security of society itself, essentially of the dominant social groups that was ultimately called into question by the extent of social problems.

The polarization around two different positions in the responses to be implemented was immediate and still remains valid. On one hand, there are those who defend the identification and accountability of parents who put their children at risk socially; on the other hand, there are those who believe the solution of the social problem lies in the reorganization of the institutions and the State (Digneffe, 1995).

Child protection must, of course, always focus on the child's well-being. If in the beginning, in the 19th century, the concern was restricted to a moral judgment on the working class and what was going on within it, since then, other concerns have emerged. Through the validation of childhood as a social category, initiated in the second half of the 20th century in western societies, the situation began to change. From a conception strictly centred on the child's dependence on the adult, another began to surface centred on the child as a subject of rights and the specific condition of childhood.

The focus of attention went beyond the intra-family sphere to examine also a wide variety of environments and contexts for the child's socialization (schools, day-care centres, associations, institutions, etc.) and the community itself. The emerging social frameworks and new methods of sociological research contributed to this process, which tended to focus on the analysis of different social problems. New awareness of previously concealed cases or those with different levels of visibility became part of the discussion and debate.

More than the possible increase in social risks, what we may be seeing today is a potential rise in daily occurrences because of the additional visibility that certain actions acquire, partly as a result of permanent media coverage.

Currently, the representation of childhood focuses on the need for its protection and the development of policies that enforce the Rights of the Child, proclaimed in 1989, through the Convention on the Rights of the Child. The view of the child implicit in the Convention on the Rights of the Child nullifies the previous conception of the child as an object, the "property" of his / her parents / family, and is also clear that the child should be regarded as 
a full person in society, a member of a family and a community, with rights and responsibilities appropriate to age, maturity and development. This is not a helpless person in need of mere charity or assistance. The child is a citizen, with recognized rights, and for this to be possible, the State is also responsible for ensuring that the family has adequate and necessary support to ensure the protection and development of the child.

But reality shows the ambivalence of individuals and social groups when faced with these issues and situations, and tensions between protection and participation, and dependence and autonomy, remain and are reproduced in the most varied social fields.

The reflexivity that characterizes contemporary Western societies has resulted in the (re) discovery of the social risks that progress through childhood, clearly showing how the lives of many children, in different parts of the world, are affected by constraints of a diverse nature. We are experiencing a period of civilizational transition marked by technological and economic progress whose repercussions, positive and negative, are felt at all levels of human action (Beck, 2016).

The growing concerns nowadays, for example, about childhood obesity, mental health, behavioural problems or the uses of the internet and digital technologies by children, all stem from the same desire to protect children. There is an increasing complexity which corresponds to the demand for the greater efficiency and effectiveness of public policies for children. The purpose of these policies should be the organization of a child protection system, which does not guarantee only its protection from serious damages (physical, psychological or sexual) but also above all ensures that children live and grow under appropriate and effective care that strengthens their rights.

Childhood protection is based on a delicate balance between the relationships of child and parent, citizens and the State, in contexts where access to equal rights is real and not merely formal. It is this principle that justifies and legitimizes State intervention in the regulation of the private and public spheres. However, overcoming conflicting discourses and practices and moving from "law-in-books" to "law-in-action" (Santos, 1986, p. 180) remains the greatest challenge in the present time in Western societies. This applies not only in the area of childhood, but also demands going beyond the marginal space that child protection continues to occupy on the public, political and academic agenda. 


\section{Referências / References}

Beck, U. (2016). The Metamorphosis of the World. Cambridge, UK/Malden, MA: Polity Press.

Digneffe, F. (1995). Problèmes sociaux et représentations du crime et du criminel. De Howard (1777) a Engels (1845) (pp. 137-212). In C. Debuyst, F., Digneffe, J-M., Labadie, \& A. P. Pires (Eds.), Histoire des Savoirs sur le Crime \& la Peine (pp. 137-212). Bruxelles: De Boeck-Wesmael s.a.

Gill, T. (2007). No Fear. Growing Up in a Risk Averse Society. London: Calouste Gulbenkian Foundation, United Kingdom Branch.

Santos, B. S. (1986). Social Crisis and the State. In K. Maxwell, (Ed.), Portugal in the 80's: Dilemmas of Democratic Consolidation (pp. 167-195). New York / Westport, CT / London: Greenwood Press. 